\title{
ORIGIN OF ARCHEAN CRATONS BY DIAPIRIC ASCENT OF FOUNDERED SHALLOW RESIDUES
}

\author{
Roberta L. Rudnick ${ }^{1}$ and Claude Herzberg ${ }^{2}$ \\ 1. Department of Geology, University of Maryland, College Park, MD 20782; \\ 2. Rutgers University, New Brunswick, New Jersey, USA
}

Archean cratons are stable regions, typically within continental interiors, that have not been significantly deformed since their formation. Because of their long-term stability, cratons are generally considered to be strong in relation to the surrounding lithosphere, which is typically composed of "mobile belts" of Proterozoic or younger age that experienced one or more orogenic events since formation. The strength of Archean cratons relative to mobile belts is often attributed to the presence of a thick, refractory peridotitic keel that extends to depths of 150 to $200 \mathrm{~km}$ (e.g., Lee, 2006, Arndt et al., 2009, and references therein). These keels are compositionally distinct from post-Archean lithospheric mantle (Boyd, 1989), having higher forsterite content and lower $\mathrm{Al}_{2} \mathrm{O}_{3}$ and $\mathrm{CaO}$, which are attributed to a greater extent of melt depletion than for their post-Archean counterparts; on the order of 30-50\% (Boyd et al., 1985, Bernstein et al., 1998, Herzberg, 2004, Lee, 2006). A wealth of Os isotope model ages shows that these keels formed in the Archean, close to the time of the formation of the overlying continental crust (Walker et al., 1989, Pearson et al., 2003).

A number of scenarios have been presented to explain the distinctive features of Archean cratonic mantle lithosphere and have been reviewed thoroughly in recent literature (Lee, 2006, Arndt et al., 2009, Aulbach et al., 2011). Salient features of each scenario, along with pros and cons, are summarized in the Table below.
Two often overlooked observations need to be accommodated in any successful scenario to explain the formation of Archean cratons: 1) the near-absence of complementary melts (e.g., high$\mathrm{Fe}$ and $\mathrm{Mg}$ basalts or komatiites) in the overlying crust or within lithospheric mantle, and 2) the presence of transition zone or lower mantle phases within diamonds derived from kimberlites that sample Archean lithospheric mantle keels (e.g., Stachel et al., 2005, Harte, 2010, Walter et al., 2011 and references therein). None of the scenarios outlined in the Table can account for both of these observations. In addition, there is evidence for relatively low-pressure petrogenesis of the residues (namely, the lack of residual garnet), but, at the same time, evidence that some of the lithospheric materials were generated at exceedingly high pressures (e.g., transition zone and lower mantle diamond inclusions). These seemingly contradictory observations require a scenario that accommodates both a low- and highpressure origin for the lithospheric mantle.

We propose that the highly refractory peridotites formed during adiabatic melting in divergent plate settings in the Archean, generating a thick, high-Fe and $\mathrm{Mg}$ basaltic crust and underlying, complementary Fe-poor harzburgite residues. When this lithosphere cools, its high density causes it to subside, driving phase changes (basalt to eclogite) that create an added downdragging force that contributes to foundering and possibly triggers subduction; concurrently, 


\section{0 $^{\text {th }}$ International Kimberlite Conference, Bangalore - 2012}

basaltic crust partially melts to generate Na-rich granites of the tonalite-trondhjemite-granodiorite (TTG) family. As the sinking lithosphere heats up during its descent, the viscosity decreases. At a critical viscosity point, the high-density residual eclogites separate from the underlying low-density harzburgites. The former sink into the deep mantle, whereas the buoyant, refractory harzburgites ascend as buoyant diapirs to underplate continental crustal nuclei composed of TTG and basalt. Small portions of residual eclogite may be entrained in these harzburgite diapirs and are sampled as xenolithic eclogites in kimberlites. Rare diamonds that grew at depth within the transition zone or lower mantle in either eclogite or harzurgite lithology may be entrained within buoyant harzburgites and dunites on their ascent to underplate proto-continental lithosphere.

Table: Competing Scenarios for Formation of Archean Lithospheric Mantle Keels

\begin{tabular}{|c|c|c|}
\hline Scenario & Pros & Cons \\
\hline Plume melting & $\begin{array}{l}\cdot \text { Produces large } \% \text { melt } \\
\cdot \text { May produce compositionally } \\
\text { stratified lithosphere, more refractory } \\
\text { near top } \\
\cdot \text { Explains lower mantle diamond inclusions }\end{array}$ & $\begin{array}{l}\text { No evidence for residual garnet, } \\
\text { which should be present } \\
\cdot \text { Where's the komatiite? (should create } \\
45 \mathrm{~km} \text { thickness of komatiite, assuming } \\
\text { minimum of } 30 \% \text { melting). }\end{array}$ \\
\hline $\begin{array}{l}\text { Stacking of oceanic } \\
\text { lithosphere }\end{array}$ & $\begin{array}{l}\cdot \text { Accounts for eclogite with oceanic crustal } \\
\text { affinities } \\
\cdot \text { Explains dipping seismic reflectors } \\
\cdot \text { Consistent with petrological evidence for low } \\
\text { melting pressures and lack of residual garnet }\end{array}$ & $\begin{array}{l}\cdot \text { Not enough eclogite present } \\
\cdot \text { Lithosphere is dynamically unstable } \\
\text { (high density overlying low density) } \\
\cdot \text { Does not explain lower mantle diamond } \\
\text { inclusions }\end{array}$ \\
\hline $\begin{array}{l}\text { Fluid-fluxed } \\
\text { melting of residual } \\
\text { peridotite within } \\
\text { mantle wedge }\end{array}$ & $\begin{array}{l}\text { - Produces refractory peridotite without } \\
\text { producing komatiite } \\
\cdot \text { Consistent with petrological evidence for low } \\
\text { melting pressures and lack of residual garnet }\end{array}$ & $\begin{array}{l}\text { - Lack of subduction zone signature in } \\
\text { cratonic peridotites } \\
\cdot \text { Anhydrous residual peridotites } \\
\cdot \text { Lithosphere is dynamically unstable } \\
\text { (high density overlying low density) } \\
\cdot \text { Does not explain lower mantle } \\
\text { diamond inclusions }\end{array}$ \\
\hline
\end{tabular}

\section{References}

Arndt, N. T., Coltice, N., Helmstaedt, H. \& Gregoire, M. (2009). Origin of Archean subcontinental lithospheric mantle: Some petrological constraints. Lithos 109, 61-71.

Aulbach, S., Stachel, T., Heaman, L. M., Creaser, R. A. \& Shirey, S. B. (2011). Formation of cratonic subcontinental lithospheric mantle and complementary komatiite from hybrid plume sources. Contributions to Mineralogy and Petrology 161, 947-960.

Bernstein, S., Kelemen, P. B. \& Brooks, C. K. (1998). Depleted spinel harzburgite xenoliths in tertiary dykes from east Greenland: Restites from high degree melting. Earth and Planetary Science Letters 154, 221-235.

Boyd, F. R. (1989). Compositional distinction between oceanic and cratonic lithosphere. Earth and Planetary Science Letters 96, 15-26.

Boyd, F. R., Gurney, J. J. \& Richardson, S. H. (1985). Evidence for a $150-200-\mathrm{km}$ thick Archean lithosphere from diamond inclusion thermobarometry Nature 315, 387-389.

Harte, B. (2010). Diamond formation in the deep mantle: the record of mineral inclusions and their distribution in relation to mantle dehydration zones. Mineralogical Magazine 74, 189-215.

Herzberg, C. (2004). Geodynamic information in 


\section{0 $^{\text {th }}$ International Kimberlite Conference, Bangalore - 2012}

peridotite petrology. Journal of Petrology 45, 25072530.

Lee, C. T. (2006). Geochemical/petrologic constraints on the origin of cratonic mantle. In: Benn, K., Mareschal, J.-C. \& Condie, K. C. (eds.) Archean Geodynamics and Evnironments. Washington, D.C.: American Geophysical Union Monograph, $89-114$.

Pearson, D. G., Canil, D. \& Shirey, S. B. (2003). Mantle samples included in volcanic rocks: xenoliths and diamonds. In: Carlson, R. W. (ed.) The Mantle and Core, Treatise on Geochemistry. Amsterdam: Elsevier.
Stachel, T., Brey, G. P. \& Harris, J. W. (2005). Inclusions in sublithospheric diamonds: Glimpses of deep Earth. Elements 1, 73-78.

Walker, R. J., Carlson, R. W., Shirey, S. B. \& Boyd, F. R. (1989). Os, $\mathrm{Sr}, \mathrm{Nd}$, and $\mathrm{Pb}$ isotope systematics of southern African peridotite xenoliths: implications for the chemical evolution of the subcontinental mantle. Geochimica et Cosmochimica Acta 53, 1583-1595.

Walter, M. J., Kohn, S. C., Araujo, D., Bulanova, G. P., Smith, C. B., Gaillou, E., Wang, J., Steele, A. \& Shirey, S. B. (2011). Deep Mantle Cycling of Oceanic Crust: Evidence from Diamonds and Their Mineral Inclusions. Science 333, 54-57. 